\title{
Papers
}

Explorations into Children's Literature

\section{A Narrative Experiment: \\ From the Revived Oral Tradition in Haroun and The Sea of Stories to Staccato Gaming in Luka and The Fire of Life \\ Yiyin Laurie Lee}

In an attempt to represent the hybrid culture of a postcolonial India, Salmon Rushdie strives for aesthetic experiment and political assertion through his signature technique, magical realism. Compared to Rushdie's other works, his two books for children, Haroun and the Sea of Stories (1990) and Luka and the Fire of Life (2010), seem light-hearted and fairy-tale-like, as child protagonists miraculously solve their problems through magic (the novels will hereafter be referred to as Haroun and Luka). These two novellas, written by Rushdie to entertain his sons, Zafar and Milan, illustrate how child protagonists can understand and solve problems in their world by exploring magical worlds and restoring the importance of storytelling. The two novellas also reflect Rushdie's consistent worry about young people tasked with diversifying personal, cultural, and political discourses so as to improve society and enrich culture.

Haroun relates how Haroun travels to a magical world to help recover the storytelling ability of his father, Rashid. Without this ability, Rashid cannot earn his living to raise his family. Moreover, Soraya, Rashid's wife and Haroun's mother, suddenly stops singing, discredits the power of narration, and elopes with a neighbour, Mr. Sengupta. Meanwhile, the tyrannical politician Buttoo threatens to kill Rashid and Haroun if Rashid cannot sing Buttoo's praises and appeal to his constituency. After Haroun is accidentally brought to the magical world, he 
finds that all his father's stories originate from the reality of this alternative world. This magical world is, however, on the verge of peril: the arch-enemy Khattam-Shud and his associates the Chupwalas wage war against the Guppees, who enjoy talking, by polluting the sea of stories, ruining all stories, and kidnapping the princess of the city of Gup. Only by winning the war against Chupwalas can the peace of this magical world be restored. The victory of the war will also allow stories and the art of storytelling to thrive. As Rashid regains his power of storytelling, he and Haroun return to their world, and their problems are also simultaneously redressed: they escape the death threat posed by Buttoo, and Soraya, who once again believes in the power of storytelling, reunites herself with the family.

While Haroun focuses on how to revive the art of storytelling through its depiction of the characters' adventures, Luka demonstrates an attempt to seek new possibilities of narration by blending computer games with storytelling. Luka, Haroun's younger brother by eighteen years, leaves his own world to enter a magical world after Rashid falls into a mysterious deep sleep. Luka later realises that this magical world is mainly constituted by his father's narrated stories and characters (Rushdie 2010, p. 180). In order to steal the Fire of Life from the magical world so as to awaken his father in his world, Luka needs to use and recall literary knowledge he has learned from his father's stories. Not only does Luka eventually awaken Rashid but he also helps preserve Rashid's created characters and stories. Luka himself also becomes a storyteller of a kind.

In biographical readings of the novellas, critics have related their themes and plots to Rushdie's response to the fatwa to which he was sentenced in 1989 after the publication of The Satanic Verses (1988). Catherine Cudy and Yael Maurer both point out that Haroun can serve as an allegory in which Rushdie launches criticism on the forces that aim to silence him (Cudy 1994, p. 388; Durix 1994, pp. 343-345; Maurer 2014, 'Haroun and Shalimar'; Teverson 2013, p. 76). Cudy suggests that the archenemy in Haroun, Khattam-Shud, can be viewed as 'Khomeini, the voice of the fatwa' (Cudy 1994, p. 338). Moreover, Kimberley Reynolds notes that Rushdie avidly played computer games after the fatwa and hence incorporates computer game features in the writing of $L u k a$ (Reynolds 2011, p. 74). As the two novellas are located in a family setting, Rashid, the father and the maestro storyteller, mirrors the writer and father Rushdie. Episodes of fighting against tyrannical authorities may 
reflect Rushdie's response to the affliction of the fatwa, which forbids him from reaching out to his children.

Departing from the biographical approach that associates episodes in stories with real events in Rushdie's life, I suggest that the two novellas propose that fictional worlds and characters can expose diverse aspects of reality and that the complexity of reality can be better understood through 'narrativisation,' the composition of a narrative (Smith 104). I will resist the temptation to fully identify the character Rashid with the writer Rushdie, regardless of their many similarities. I suggest that the dynamic relationship between magical worlds to which characters travel and characters' world broadens the domestic scope of the two novellas and urges experiments about how multiple media can help form a narrative. This may help readers acknowledge how narrativisation can shed light on life; that is, one may understand everyday life experiences better by transforming them into narratives (Smith 104).

I will draw on Reynolds's discussion about how multiple media might transform the nature of narration to explore how Luka and Haroun propose that oral tradition, written tradition, and the narrative traditions of other media can enrich narration. Haroun and Luka share the themes Rushdie always privileges: defiance of oppressive authorities and endorsement of freedom of speech. The two novellas also highlight two questions: where are storytellers located nowadays, and do we still need storytellers? These two questions have high relevance to contemporary culture where multiple media prevail. I regard the two novellas as narrative experiments initiated by Rushdie rather than his final answer to the two questions I pose above.

\section{Transtextuality and Transmediality}

In the digital era, some educators, parents, and critics worry that increasing digitisation and the development of the internet may prohibit children from acquiring full literacy, as the quantity and quality of their reading decrease. Nicholas Carr argues in The Shallows: What the Internet Is Doing to Our Brains that when people get used to skimming and skipping pieces of information, many of them find it more difficult to conduct lengthy, deep reading 
and thinking (Carr 2010, pp. 5-8). As people adjust their brains to the mechanism of the internet and digital devices, they read and think in a fragmentary, 'staccato' way (p. 7). Daniel Bell notes that the development of technology, intellectual technology in particular, can alter people's perception of the world and affect their ways of living. As he notes, 'an intellectual technology is the substitution of algorithms (problem-solving rules) for intuitive judgment' (Bell 1973, p. 29) and is concerned with “"ordering” the mass society' (p. 33). As people continue to enjoy technological and digital texts, technology may alter their cognitive systems, influencing their thinking about themselves and the world (Carr 2010, p. 44; Bell 1973, pp. 116-117). Carr pessimistically predicts that the majority of people will unwittingly train themselves to accept fragmented thoughts and absorb information that can only be put in a terse form, if not in catchy headlines (Carr 2010, p. 44). Carr believes that people will gain instant gratification through rapid exchanges of messages and information at the expense of their ability to concentrate and contemplate on important issues and ideas in life.

In contrast to Carr's pessimistic view of how digitisation might radically change people's cognitive system and transform them into shallow people without the capacity to think deeply, Reynolds suggests that children's literature, with its amorphous and flexible character, can abate that worry: transmedia have radically changed the narrative nature of children's literature, yet they also enrich narrative and self-expression. Reynolds notes:

That the oldest forms of literature are receiving cutting-edge treatments is a reminder that through stories, children are simultaneously inducted into literary tradition and taught the skills that will make them fully literate in terms of their own time. (Reynolds 2011, p. 64)

The reproduction of traditional tales through new media or the blending of literary traditions into new narratives helps children familiarise themselves with cultural heritage passed down by previous generations. Under the sway of digitisation, young audiences can become more resourceful in composing and exploring diverse stories through varied media.

Like Henry Jenkins, Reynolds argues that children are now gaining 'cultural literacy' through the diverse ways in which they 'encounter narratives' (Reynolds 2011, p. 62; Jenkins 2006, p. 186, p. 2, p. 11). As Reynolds observes, children learn stories not only from printed books but 
also from other media such as animation or performance (Reynolds 2011, p. 61). The print text thus no longer serves as the only way to gain literacy, but children acquire 'transliteracy' through their interaction with transmedia (Reynolds 2011, p. 65): 'Movement between media is often encouraged through remediation (also called transmediation) strategies, meaning the way new media tend to ingratiate themselves with audiences by referencing, mimicking, or even incorporating established media' (p. 65). In Reynolds's view, even if children now read fewer print texts, they do not necessarily become less culturally informed:

The reservoir of stories is not stagnant but constantly refreshed and replenished, so every generation of children is also given new stories that speak to current needs, interests, and concerns. Familiarity with new tales and texts is also part of what it means to be culturally literate ... [and] new stories are often the product of interactions with new media. (Reynolds 2011, p. 62)

Through access to transmedia, young people are able to form 'narrative networks' which, in turn, characterise better the cultural literacy they are acquiring: 'multiple versions of texts are being generated as parts of interconnected and coordinated networks constructed by media conglomerations' (Reynolds 2011, p. 66). A core story is reiterated, reproduced, and innovated, and reinvented in different formats. Multiple versions of texts, instead of competing to constitute the best production, complement one another in terms of characterisation, plotting, setting, and so on (p. 67). Although she praises the potential of transmedia to enrich narratives, Reynolds does not ignore the fact that narrative networks are deeply enmeshed in consumerist culture and society (Reynolds 2011, p. 67).

In Reynolds's view, narrative 'transtexts' demonstrate how print texts can be integrated with the features of other media (Reynolds 2011, p. 76). In Haroun, the juxtaposition of oral tradition and written tradition implies the tension between speech and writing, and the fairytale-like story also incorporates sci-fi and realistic elements. Dynamic oral traditions become standardised in written texts, in which magic coexists both with scientific development and mundane life. In Luka, the narrative of Luka's adventure in a magical world is devised as levels of a video or computer game. To accomplish his mission, Luka has to use his literary knowledge to overcome obstacles at each level (Rushdie 2010, pp. 74-75). ${ }^{1}$ Although some game theorists maintain that games should focus on strategies to enable players to enjoy gaming, narratives in games nevertheless can provide background information about a game 
world (Egenfeldt-Nielsen, Smith, and Tosca 2013, p. 214, pp. 200-202). Despite the differences between devising a game and writing a novel, Luka shows that transtexts can involve the developing features of video or computer games in a narrative that emphasises players' interaction with a text: by interpreting hints provided in a game to solve problems, players map the game world as well (Reynolds 2011, pp. 72-73). ${ }^{2}$ Luka may remain a print text, yet it evokes a 'collaborative style of reading' that contains the three key elements of transtexts: interactivity, (intrinsic) interpersonality, and immersion (p. 71). If readers align with the child protagonist Luka, they form something like an interpersonal relationship with him, and by seeing him through his journey, readers interact with other characters as they immerse themselves in his adventure (p. 71). Haroun also incorporates features that can be regarded as transtexts. It blends oral tradition and written tradition, with both of which readers are very familiar. Haroun also reminds readers of experiences of listening to or reading stories. Readers can identify as engrossed game players like Luka or committed listeners to stories like Haroun. ${ }^{3}$

Although Gerard Genette does not directly explore how multiple media may revolutionise narration, his idea of transtextuality may help illuminate the probable chemistry of "narrative networks'-young people's relationships with narratives and with other people (Genette 1982, pp. 1-10; Allen 2000, pp. 97-115; Smith 2007, p. 13). ${ }^{4}$ New stories may reveal new perspectives of former stories. Previously-told stories may provide knowledge to help readers interpret new stories. The narrative of Luka reveals new way of understanding Haroun as the two novellas create an intertextual network. If Haroun raises readers' awareness of the value of oral storytelling to resist the domination of written tradition, Luka further demonstrates that that oral tradition, written tradition, and the narrative elements of a video or computer game can be effectively blended. Further, transtextuality refers to how readers of different ages and at various times respond to narratives. Readers' own knowledge of literary tradition, their understanding of new media, and their interpretations of a (trans)text complicate narrative networks.

As Haroun serves as the intertext and hypotext for Luka, Haroun introduces a major theme of both novellas: the (re)discovery of the art of storytelling and the impact of stories on real life (Rushdie 1990, p. 338). ${ }^{5}$ Haroun and Luka's hometown, the Valley of K., eventually 
recovers its original name, 'Kahani' ('story'), but other meanings associated with 'K.' enhance the significations of Haroun and Luka's hometown (Rushdie 1990, p. 209). In Haroun, the ' $\mathrm{K}$ ' also refers to the ' $\mathrm{K}$ ' of 'Kache-Mer,' 'the place that hides a Sea' (p. 40). It implies the link between the Valley of $\mathrm{K}$ and the magical world where the sea of stories lies; accordingly, the Valley of K regains its name after Haroun saves the sea of stories from being polluted. The K may also indicate the ' $K$ ' of 'Kosh-Mar,' 'nightmare' (p. 40), an association which suggests that while stories can be comforting and entertaining, they can also be disastrous and nightmarish. As demonstrated in Haroun and Luka, stories that go awry endanger child protagonists' lives. A biographical reading of Haroun may render $\mathrm{K}$ as Kashmir, Rushdie's desired homeland: 'The Valley of K is Rushdie's re-imaginary of Kashmir as an Eden on earth' (Maurer 2014, 'Haroun and Shalimar'; Teverson 2013, p. 76). That is, stories help create a sense of home and of belonging. Cudy further points out another association with $\mathrm{K}$ : the ' $\mathrm{K}$ ' of 'KASHF' - 'discovery, in which the meaning of faith and truth is given in experimental immediacy to the seeking soul' (Cudy 1994, p. 338). The multiple associations of $\mathrm{K}$ thus complicate what ' $\mathrm{K}$ ' stands for. In this sense, to continue discovering the impact of stories helps refresh the significance of one's identity, origins, and hometown.

\section{Where Are Storytellers Located Nowadays?}

In 'The Storyteller: Reflections on the Works of Nikolai Leskov,' Walter Benjamin laments that the singular, energetic, interactive storyteller disappears in the age of mechanical production and is replaced by an impassive, egoistic, reclusive novelist (Benjamin 1970, p. 87). Traditional storytellers create a congenial milieu where they can display their personal charisma and change their narratives in accordance with their audience's immediate reactions. Novelists, on the other hand, cannot instantly know their readers' responses to their narratives, and they become lone artists, isolated from their communicative communities. As telling a story becomes a private, solitary act, reading also becomes private: readers glean help from either novelists or fellow readers in understanding stories (p. 99). The possibility of face-to-face encounters between a storyteller and listeners became less possible when the publishing business developed in the era of industrialisation. People no longer gleaned knowledge and information by word of mouth but through printed texts. Print texts also indicate that what readers receive is standardised in quality and quantity. 
Even though Benjamin worries that knowledge, information, and stories may become standardised and alienated from receivers in commodified genres of books, pamphlets, manuals, etc., in today's society, storytelling does not seem to lose its enchantment. Today's storytellers may not exactly resemble traditional ones, but they still occupy an important place in children's literature. An adult who delivers a story to a child listener can be a storyteller. In fiction, a storyteller can be a narrator who directly addresses a child reader. Moreover, a storyteller can assume many other roles in modern novels. For example, narrators in metafictional texts are often storytellers who explore the art of storytelling. Kevin Paul Smith also argues that instead of disappearing from the literary arena, oral storytellers are transformed into 'novelistic storyteller[s],' 'a metafictive trope' that unveils 'the process of narration and the complexity of the boundaries between speech and writing' (Smith 2007, p. 88, pp. 96-97). Authors of novels differ from traditional oral storytellers as readers interact with stories through print texts (p. 96). However, when authors function at intradiegetic or homodiegetic levels, they tend to produce self-reflexive texts which lay bare the tensions not only between speech and writing but between narratives and real life (p. 92). Storytelling traditions can be customised according to demand, as mass products fail to gratify most people's needs. If new media revolutionise the traditions surrounding print texts, new social media such as twitter, facebook or online forums can create new opportunities for readers to exchange their ideas and make reading a collaborative process. In this sense, the face-to-face interaction between a storyteller and listeners can be revived, if not preserved, in a virtual, digital way.

While reading Haroun and $L u k a$, readers may ponder the complicated relationships between a story, a storyteller, a listener, and a real life. As Jean-Pierre Durix suggests, the two novellas touch on various aspects of storytelling (Durix 1994, p. 346). Storytellers who become characters in printed books create a kind of narrative tension: how can a communicative literary figure survive when cast into an alienated world? In the novellas, Rashid enlightens other characters with his stories. Although readers are informed of the import of Rashid's stories, they rarely learn their details. Rashid's narrative voice is significantly toned down, and he needs his sons' help to maintain his life and continue his career of storytelling. In Haroun, with his power restored, Rashid starts telling a story about the adventure Haroun has experienced: 'As you have guessed, Rashid told the people in that park the same story I've just told you ... his account ... was so accurate' (Rushdie 1990, p. 
206). Since Rashid knows all the details of Haroun's adventure without participating in it, Haroun supposes that 'his father must have asked Iff and the others about [it]' (p. 206). Readers, nevertheless, may wonder about the mysterious link between the omniscient narrator of Haroun and the character of Rashid: stories circulate and evolve in accordance with how a storyteller delivers them, yet Haroun's adventure (real to characters yet fictional to readers) is not only reported but scripted so that it can be consumed repeatedly. In this sense, print texts help preserve oral stories, ensuring that they will not die out due to the disappearance of traditional storytellers. The publishing industry further enables the stories to be distributed to the wider public. Haroun, a print text, can remind readers of the import of oral tradition that once connected storytellers and listeners in a cosy communicative community. Through their deployment in Haroun, oral traditions make a lasting impact on the culture and society of new generations.

Haroun's and Luka's expedition to rescue their father, Rashid, the maestro storyteller, turns out to be a cultural movement to preserve the heritage of storytelling and oral tradition, rather then merely a personal act to save a beloved family member. Haroun and Luka, who used to be the audience of Rashid's stories, take action to remedy magical worlds, and their adventures impact on both their lives and magical worlds. Haroun conserves the sea of the stories in the magical world so that his family can continue to enlighten others with stories. Luka makes characters in his father's created world, recognises their close relationship with the storyteller and confirms that stories can live on as long as they are continuously told. As Haroun and Luka inherit the family legacy and pursue the career of storytelling, they also denote young people's capacity for using different literary traditions to produce new expressions and their own stories.

While Haroun is narrated in a traditional, linear way, Luka presents the child protagonist's adventure in the circular, recursive mode of a video or computer game: Luka completes his heroic quest by entering a level, finishing an assignment, and moving on to the next level (Teverson 2013, p. 77). On the one hand, to depict the process of saving a father's life as winning a computer game may trivialise Luka's mission, as it turns a matter of life or death into a game. The staccato logic of a game, similar to fragmented information or knowledge, cannot equip game players to handle big challenges in life comprehensively. On the other 
hand, the division of a large mission into many, recursive assignments assists game players by presenting a simplified version of a lofty quest. For Luka, the virtual reality of the game closely relates to his world, and the actions he takes in the game world affect his real-world experience. Luka then suggests that circular, recursive processes, actions, and thinking patterns can coexist with linear, progressive ones.

Luka's adventures in the game world suggest that by completing small tasks, people can accomplish a lofty mission in life. Simon Egenfeldt-Nielsen, Jonas Heide Smith, and Susan Pajares Tosca point out that '[a]ctual gameplay is full of trial and error ... [A video or computer game] is perpetually unfolding, constantly folding back on itself, full of false starts and restarts, as the player contributes to the story's creation with each action' (EgenfeldtNielsen, Smith, and Tosca 2013, p. 212). Recurrent assignments may not be boring repetitions but allow game players to try different ways to solve problems. As the magical world created by Rashid turns into a game world to engage Luka, it suggests that even if storytelling or gaming routes are different, they may lead to the common goals of making meaning of culture, life, and world. Relying on the literary knowledge he learns from his father, Luka finds clues to complete assignments at different levels (Rushdie 2010, p. 102). Eventually, he not only participates in reforming the World of Magic but finds his own way to solve a problem: 'Left . . That's the answer. I went right, and fell into the World of Magic. Now maybe if I somehow go left, I'll find my way through it' (p. 162). After finding the clue, he had 'Jumped to the Left, from a Mountain of Difficulty to a Hill of Ease, and the Fire of Life lay within his grasp' (pp. 168-174). Luka's decision to go left instead of right provides him a new perspective to access the magical world. Although the magical world is invented by his father, the game changes to favour Luka due to the decision he makes and the action he takes. Moreover, entering the World of Magic and playing the game well strengthens Luka's familial and emotional link with his father, and by extension, the cultural conventions his father inculcates in him. At last Luka becomes a capable storyteller who can transform his father's stories into his own.

Haroun and Luka show how children can be continuously fascinated with stories and how storytelling, in turn, helps them comprehend the sophistication of their world and life. Does it matter if storytellers have disappeared? It does if stories perish and disappear with them. 
Nevertheless, listeners become potential storytellers who will pass on stories and literary convention to the next generation while adding their own variations. Children nowadays may encounter narratives in different ways, but the tradition of storytelling has always been preserved and demonstrated in literature for young people. Literature for young people consistently reminds people of their desire for stories and of the personal, familial, social and cultural import of storytelling.

\section{Do We Still Need Storytellers?}

In a digital era, we continue to value stories and storytellers for their literal and metaphoric significance. In Luka, the character Nobodaddy, the incarnation of Death, claims that 'Man is the Storytelling Animal' (Rushdie 2010, p. 34; Gottschall 2013, p. 87). Likewise, Jonathan Gottschall, in his book The Storytelling Animal: How Stories Make Us Human, draws on literary criticism and evolutionary psychological studies to argue that humans need stories and that they have to circulate and tell stories to themselves and others. Gottschall also recognises the nightmarish quality of stories. As he suggests, instead of offering happy endings or wishful plots to provide escapism from tedious everyday life, stories reflect various troubles and problems people may suffer from (Gottschall 2013, pp. 45-67). Stories, nonetheless, create an alternative space where people can tackle their problems from another perspective, in a more imaginative, symbolic way (pp. 45-67). This may explain why Haroun's and Luka's adventures in magical worlds help them solve problems in the world they come from. Besides, through reading fiction, readers may also enrich their experiences by identifying themselves with heroes and immersing themselves in various quests, while avoiding the tragic falls of heroes (pp. 45-67).

In Haroun, Haroun experiences a crisis of faith in his father's storytelling career: 'What's the point of it? What's the use of stories that aren't even true' (Rushdie 1990, p. 22). Haroun later regrets his scepticism, for he finds he has difficulty going beyond the duration of eleven minutes as if he were cursed by his abandonment of the art of storytelling. Cudy points out that '[Haroun] both sets out to answer the question in the course of the narrative, by recounting the fantastic adventures of Haroun, and effectively is the answer to the question itself' (Cudy 1994, p. 337). What really matters is not how true a story can be but what truth a 
story and storytelling can reveal: 'Fiction is a powerful and ancient virtual reality technology that simulates the big dilemmas of human life' (Smith 104; Gottschall 2013, p. 67). For example, homodiegetic storytellers expose the process of narrativising life experiences and thus render illusionary the notion that reality is the antithesis to fictionality. Reality is relevant to fictionality.

In Luka, the protagonist's discovery that the World of Magic is constructed does not ruin the significance of Luka's adventure but grants him agency. When Luka realises the World of Magic is his father's invention, he defies the intervention of godlike figures into his mission: 'It's only through Stories that you can get into the Real World and have some sort of power again. When your story is well told, people believe in you . . It's only my father, and people like him, who can give it you now' (Rushdie 2010, p. 182). Mythical gods, semi-god figures, and famous heroes come to acknowledge their symbiosis with Rashid the storyteller. By telling and retelling tales associated with these figures, cultural traditions, can be remembered, reproduced and passed on. Luka explains, 'I have been hearing about [the World inside Rashid's head] every day of my life ... So in a way it's now my World, too' (Rushdie 2010, p. 181). Moreover, in the magical world, Luka meets famous literary figures who stole the Fire of Life, the Algonquin Indians, Rabbit, Coyote, Beaver, Nanabozho the Shape-Shifter, Prometheus (Rushdie 2010, p. 149). They pass down their experiences to Luka and involve him in the community of these fire thieves. Luka further challenges linear time's power to annihilate his father's life and his stories. As he becomes the proprietor of a magical world, he helps to renew stories to withstand the test of linear time. As Iff, the genie in Haroun, states, 'no story comes from nowhere; new stories are born from old-it is the new combinations that make them new' (Rushdie 1990, p. 86). Digitised data and the development of the internet allow easy access to diverse cultural resources, which can be recognised and employed in the production of new narratives.

As well as the possibility that a storyteller can reveal the process of storytelling, the interdependent relation between Haroun and Luka's family and the magical worlds of the novellas indicates that reality may incorporate many levels, and that these levels are interconnected. As suggested in the novellas, magical worlds created by storytellers allow listeners or readers to discover other aspects of reality and perspectives on life. Luka learns to 
tackle Death, the archenemy of humans, and cushion the lethal impact of Death's ally, linear time, in the magical world. Rashid tells Luka,

Dreams are the Aalim's [The Trinity of Time's] enemies, because in dreams the laws of Time disappear ... the time of our feeling is not the same as the time of the clocks ... Our dreams are the real truths-our fancies, the knowledge of our hearts. We know that Time is a River, not a clock ... We know that the River of Time can loop and twist and carry us back to yesterday or forward to the day before tomorrow. (Rushdie 2010, p. 132, pp. 156-57)

The magical worlds of the novellas are dreamlike chronotopes, for dreams temporarily release characters from the tyranny of linear time and urge them to think beyond daily routines and life patterns developed according to mechanical time. Gottschall notes that stories may appear as dreams, and '[a] dream is a virtual reality simulator where people and other animals hone responses to life's big challenges' (Gottschall 2013, p. 78). Through dreams, people rehearse the way to handle crises in their lives. Rushdie acknowledges that dreams are not weird worlds but visions of the future: 'In dreams begin responsibilities ... Our dreams of our own and our children's future shape the everyday judgments we make ... Daily life in the real world is also an imaged life' (Rushdie 2003, p. 436). Dreams are not where people retreat to avoid daily life but an important part of people's living reality. Haroun and Luka demonstrate that magical worlds enable them to understand life better.

\section{Haroun's and Luka's Narrative Agency}

Haroun's and Luka's adventures cannot be reduced to a mission to exterminate an archenemy. In these adventures, Haroun and Luka expose and question the absurdity of rigid authorities and forced consensus. Meanwhile, as they align themselves with Rashid and take on the role of storytellers, they become agential story-tellers. From their perspectives, not a single character embodies absolute evil. In Haroun, Haroun exclaims his surprise when he finds that Khattam-Shud, incarnating a destructive force, can be isolated and feeble: 'That's him? That's him? .. . This little mingling fellow? What an anti-climax' (Rushdie 1990, p. 153). Likewise, in Luka, the powerful enemy, Aalim or the Trinity of Time, the ally of Death, is a fragile figure. As Luka says, 
the Present hardly exists ... It vanishes into the Past every time I blink an eye . . . The Future is a dream, and nobody knows how it will turn out. The only sure thing is that we-Bear, Dog, my family, my friends and-we will make it whatever it is, good or bad, happy or sad, ... Time isn't a trap . . It's just the road I'm on. (Rushdie 2010, pp. 199-200)

Luka's proclamation suggests that instead of fearing the power of time to annihilate one's existence, one can focus on how to spend one's time and connections one can make with others. Moreover, when Luka assists Insultana Soraya, the Queen of Ottters, in winning the war against the Rats who maintain the façade of respectful society at the expense of dissent and nonconformity, the victory denotes an endorsement of the diversity of life and the critique of forced compliance (Rushdie 2010, pp. 69-92). Maurer argues that this war between Rats and Otters functions as a critique of British society's persistent pursuit of decorum and respectfulness (Maurer 2014, p. 158) compared to the irreverence and vitality of Indian culture. Haroun's and Luka's adventures model behaviours where individuals challenge the impossible and defy seemingly invincible authorities.

Remarkably, despite the novellas' resemblance to fairy tales, neither Haroun nor Luka provides an everlasting happy ending. The harmonious state restored by the end of Haroun is disrupted at the beginning of Luka, initiating Luka's adventure. Although Haroun and Luka eventually solve their problems and return home, their world and the magical worlds to which they travel remain under the threat of oppressive power which curbs freedom of speech and crushes individuals. Haroun and Luka may need to fight another hard battle to maintain harmony between worlds. The endings of the novellas imply that the work of facing uncertainties and threats is never done.

The novellas emphasise that sincerity and sympathy enable Haroun and Luka to look beyond appearances and to understand the merits and weakness of friends and enemies. In Haroun, freedom of speech, eloquence, and openness are praised, but silence is also valued: 'the dance of the Shadow Warrior [Mudra] showed him that silence had its own grace and beauty (just as speech could be graceless and ugly); that Action could be as noble as Words; and that creatures of darkness could be as lovely as the children of the light' (Rushdie 1990, p. 125). 
This understanding enables reconciliation rather than destruction. In Luka, Luka takes pity on the circus animals controlled and abused by Captain Aag (Rushdie 2010, p. 3). In the episode where Dog the bear, one of the escaped animals from Aag's circus, admits that he lies about his origin, Luka easily forgives him. Unlike another animal, Bear the dog, who lives an immoral life due to a Chinese curse, Dog the bear pretends to undergo a magical transformation in order to impress others. Instead of roundly condemning Dog for his dishonesty, Luka tells Dog, 'Don't worry ... This is a storyteller's house . . Everybody here makes up stories all the time' (p. 213). Luka understands why Dog lies to impress others, and appreciates that making up stories does not undermine the quest for truth or what is important in life. The novellas propose that by sincerity and sympathy individuals can help comprehend the otherness of others and, by extension, that of other worlds.

\section{From the Revived Oral Tradition to Staccato Gaming}

Both Haroun and Luka gradually acquire the competence for storytelling in their respective travels to magical worlds. After Luka's adventure, Haroun promptly recognises the transformation he himself has undergone: 'You've been somewhere, haven't you...You've been up to something ... You've had your adventure!' (Rushdie 2010, p. 208). At the beginning of Luka, Haroun believes that Luka's turn for a unique adventure will come (p. 6). Their adventures position readers to value the power of storytelling and cultural maintenance. As modern fairy tales, Haroun and Luka create cultural resources for young readers. Both novellas not only demonstrate but also celebrate the hybridity of diverse cultural elements and media, promoting what Rushdie describes 'humanitate - a form of internationalism that involves recognition of human commonalities across the borders of nation and clan' (Teverson 2013, p. 85). These texts incorporate narrative strategies which require readers to recognise the transtextual connections between cultural products, narratives and practices. Such modern fairy tales can further enable readers to recognise common problems they face so that they can search for a hard-won yet harmonious global society (p. 85).

While Haroun can be viewed as an elaborate allegory about the restoration of oral narrative traditions to modern society, Luka is a more playful piece of writing, incorporating the device of a computer game that divides a heroic quest into staccato, repetitive activities. Haroun 
unfolds the struggle of a child protagonist who has undergone a faith crisis: Haroun wants to believe in the power of stories, yet he simultaneously discredits it. Crucially, storytelling and stories cannot be finalised. While people tell different stories, consensus on important issues can be negotiated rather than being forced. Luka demonstrates that a new medium like a computer game can be used to address important issues, reinterpreting literary traditions through new media. The novella's deployment of new media encourages readers to seek their own adventures and devise their own narrative experiments.

\section{Notes}

1. Reynolds cites as examples the video games Assassin's Creed and Assassin's Creed II (Reynolds 2011, p.73).

2. As well as Luka, Reynolds refers to Diana Jones's Hexwood (1993) and Cornor Kostick's Epic (2004) (Reynolds 2011, pp. 73-76). She also calls on J.K. Rowling's Harry Potter series as a further example of a transtext (p. 67).

${ }^{3}$. Note, however, that Maria Nikolajeva questions whether child readers should be encouraged to identify themselves with young or child protagonists in narratives (Nikolajeva 2010, pp.187-208).

4. 'Transtextuality' refers to five possible relations between texts: 'intertextuality,' 'architextuality,' 'paratextuality,' 'hypertextuality,' and 'metatextuality' (Genette 1982, pp. 1-10; Allen 2000, pp. 97-115). However, relations between texts often overlap because one text can refer to others in a variety of ways.

5. Haroun and Luka cross-reference previous literary works and other cultures. Haroun is also a hypertext of previous texts; for example, The Arabian Nights. 


\section{References}

Allen, Graham (2000) Intertexuality: The New Critical Idiom. London: Routledge.

Bell, Daniel (1973) The Coming of Post-Industrial Society: A Venture in Social

Forecasting. New York: Basic Books.

Benjamin, Walter (1970) Illuminations, trans. Harry Zorn. London: Pimlico.

Carr, Nicholas (2010) The Shallows: What the Internet Is Doing to Our Brains. New York: Norton.

Cudy, Catherine (1994) 'Through Children's Window: Haroun and the Sea of Stories.' In D.M. Fletcher (ed) Reading Rushdie: Perspectives on the Fiction of Salman Rushdie. Amsterdam: Rodopi, pp. 335-342.

Durix, Jean-Pierre (1994) 'The Garden Stories': Salman Rushdie's Haroun and the Sea of Stories.' In D.M. Fletcher (ed) Reading Rushdie: Perspectives on the Fiction of Salman Rushdie. Amsterdam: Rodopi, pp. 343-351.

Egenfeldt-Nielsen, Simon, Smith, Jonas Heide, and Tosca, Susan Pajares (2013) Understanding Video Games: The Essential Introduction. $2^{\text {nd }}$ ed. New York: Routledge.

Genette, Gerard (1982) Palimmpsests, trans. Channa Newman and Claude Doubinsky. Nebraska: University of Nebraska Press.

Gottschall, Jonathan (2013) The Storytelling Animal: How Stories Make Us Human. Boston: Mariner Books. 
Jenkins, Henry (2006) Convergence Culture: Where Old and New Media Collide. New York: New York University Press.

Maurer, Yael (2014) The Science Fiction Dimensions of Salman Rushdie [Kindle Paperwhite]. Jefferson, North Carolina: McFarland.

Nikolajeva, Maria (2010) 'The Identification Fallacy: Perspective and Subjectivity in Children's Literature.' In M. Cadden (ed) Telling Children's Stories: Narrative Theory and Children's Literature. Lincoln: University of Nebraska Press, pp. 187-208.

Reynolds, Kimberley (2011) Children's Literature: A Very Short Introduction. Oxford: Oxford University Press.

Rushdie, Salman (1990) Haroun and the Sea of Stories. London: Puffin Books.

— (2003) 'Step Across This Line.' Steps Across This Line: Collected Non-fiction 1992-2002. New York: Vintage. pp. 407-442.

- (2010) Luka and the Fire of Life. London: Jonathan Cape.

Smith, Kevin Paul (2007) The Postmodern Fairytale: Folkloric Intertexts in Contemporary Fiction. Houndmill, Basingstoke: Palgrave MacMillan.

Teverson, Andrew (2013) 'Salman Rushdie's Post-nationalist Fairy Tales: Haroun and the Sea of Stories and Luka and the Fire of Life.' In R. Eaglestone and M. McQuillan (ed) Salman Rushdie: Contemporary Critical Perspectives. London: Bloomsbury Academic. pp. $72-85$. 


\section{Biographical Note}

Yiyin Laurie Lee is an assistant professor in the Department of English at Wenzao Ursuline University of Languages. Her research interests focus on contemporary young adult and children's literature, fantasy literature, and literary criticism. This article is based on a paper given at a conference held by Taiwan Children's Literature Research Associations (TCLRA) in 2014. Her previous publication (2013) can be found in Wenshan Review of Literature and Culture. 